\title{
QUALITY FUNCTION DEPLOYMENT (QFD) APPLIED TO THE VARIABLES THAT INFLUENCE QUALITY COSTS IN MECHANIZED FOREST HARVEST OPERATIONS
}

\author{
Gustavo Silva Oliveira ${ }^{1 *}$, Philipe Ricardo Casemiro Soares ${ }^{2}$, Jean Alberto Sampietro ${ }^{2}$ \\ 1*Federal University of Paraná, Department of Rural Economy and Extension, Curitiba, Paraná, Brazil - gustavo_ccp@ hotmail.com. \\ ${ }^{2}$ Santa Catarina State University, Department of Forest Engineering, Lages, Santa Catarina, Brazil - philipe.soares@ udesc.br; \\ jean.sampietro@udesc.br
}

Received for publication on: 26/06/2018 - Accepted for publication on: 17/06/2020

\begin{abstract}
Resumo
Desdobramento da função qualidade $(Q D F)$ aplicado as variáveis que influenciam os custos da qualidade em operações de colheita florestal mecanizada. A globalização e as exigências dos clientes, resultam na necessidade de investimentos para a sobrevivência das empresas. Das etapas de produção de madeira, a colheita florestal compreende os maiores custos e perdas. O desdobramento da função qualidade (QFD) é um método preconizado para atingir a qualidade detectando as necessidades dos clientes. Assim, este estudo objetivou determinar as variáveis que influenciam os custos da qualidade na colheita mecanizada, visando o controle de qualidade da atividade florestal. A pesquisa desenvolveu-se em uma empresa localizada na região do planalto catarinense, estado de Santa Catarina. Foram identificas as variáveis que influenciam os custos da qualidade em quatro categorias (avaliação, prevenção, falhas internas e externas). O método utilizado foi o QFD para traduzir as necessidades dos clientes internos e externos (fatores críticos de sucesso) das atividades de colheita mecanizada em características técnicas mensuráveis (variáveis que influenciam os custos da qualidade), determinando o peso para cada relação e consequentemente obtendo-se o balanço das categorias, além das correlações das variáveis avaliadas como: forte, média, fraca e inexistente. Dentre as 29 variáveis identificadas, 18 foram de avaliação e prevenção, representando pesos relativos de $37,17 \%$ e $26,49 \%$ respectivamente, enquanto que as 11 variáveis de falhas internas e externas representaram $26,57 \%$ e $9,73 \%$, respectivamente. Na matriz de correlações, das 406 células, foram encontradas 334 correlações: 195 (58\%) forte, 86 (26\%) média e $53(16 \%)$ fraca. Concluiu-se que a empresa deve aperfeiçoar a qualidade do processo, investindo em avaliação e prevenção visando a redução das não conformidades e expansão das receitas.

Palavras-chave: Setor florestal, planejamento, ferramentas da qualidade.
\end{abstract}

\begin{abstract}
Globalization and client demands result in the need for investments for the survival of the companies. Forest harvest represents the highest costs and losses of wood production. Quality function deployment (QFD) is recommended to achieve quality by detecting customer needs. Thus, this study aimed to determine the variables that influence quality costs in the mechanized harvest to reach the quality control of forest activity. The research was developed in a company located in the State of Santa Catarina, Brazil. The variables that influence quality costs in four categories (evaluation, prevention, internal and external flaws) were identified. The QFD method was used to translate the needs of internal and external customers (critical success factors) of mechanized harvesting activities into measurable technical characteristics (variables that influence quality costs), determining the weight for each relationship and, consequently, the balance of the categories, besides the correlations of the variables evaluated as strong, medium, weak, and non-existent. Among the 29 variables identified, 18 consisted of evaluation and prevention, representing the relative weights of $37.17 \%$ and $26.49 \%$, respectively, and 11 represented internal and external flaws, with values of $26.57 \%$ and $9.73 \%$, respectively. The correlation matrix found 334 correlation of the 406 cells: 195 (58\%) strong, 86 (26\%) medium, and 53 $(16 \%)$ weak. In conclusion, the company must improve process quality by investing in evaluation and prevention aimed at reducing non-conformities and expansion of revenues.

Keywords: Forest sector, planning, quality tools.
\end{abstract}

\section{INTRODUCTION}

The Brazilian forestry sector has been highlighted worldwide due to technological advances and the knowledge generated by decades of research, which, associated with the end of tax incentives and the reduction of stocks of raw materials, triggered the search for improving production activities.

In addition to the advances in the sector, the ongoing globalization of the economy results in increasing demands by consumers, increasing competitiveness in the industry, and raising the importance of quality

FLORESTA, Curitiba, PR, v. 50, n. 4, p. 1717 - 1724, out/dez 2020.

Oliveira, G. S. et.al.

ISSN eletrônico 1982-4688

DOI: 10.5380/rf.v50 i4. 60137 
differential for companies that wish to achieve success while remaining competitive in the national and international market.

As a measure of survival, organizations have considerably increased productivity, efficiency, and quality levels, raising the attractiveness of their products and/or services (SANTOS et al., 2019). Thus, the application of tools and methodologies that evaluate losses has great potential, given the continuous improvement of the production system.

However, the evolution and application of quality management tools and methodologies in the forestry sector are still recent when compared to other sectors. This problem occurs because of the lack of research that corroborates with process optimization and the results reach the companies. Consequently, the lack of resources invested in the control and prevention of processes generates high costs of internal and external flaws, causing customer dissatisfaction and loss of market.

According to Juran and Gryna (1993), a significant point for improving processes is an effective identification and control of variables that influence quality costs. Thus, the lack of new information regarding the quality costs of the production process, observed in the forestry sector, can trigger social, environmental, and economic losses, especially in forest harvesting and transportation activities, which represent approximately $50 \%$ of the final material costs (MACHADO, 2014).

In this context, the adaptation of Quality Function Deployment (QFD) is a potential alternative to determine the variables that influence quality costs and aims to improve the development of the production process in conjunction with customer needs to reach the guarantees expected for the activities. According to Akao and Mazur (2003), the tool is adopted in several countries, and its main objectives is to reduce time spent, mitigate customer dissatisfaction and losses, and increase intercommunication within organizations.

In this sense, Milan et al. (2003) adopted the QFD for quality planning in soil tillage activities. Soares $e t$ al. (2015) adapted the QFD method to determine performance indicators in the weed control in forest plantations. Dias et al. (2015) evaluated the applicability of this method in surveying the quality of charcoal sold for cooking.

Considering the importance of the theme, the objective of this study was to determine the variables that influence the quality costs in mechanized forest harvest, aiming to assist in the management processes of the activities of a forestry company.

\section{MATERIAL AND METHODS}

\section{Location and description of the study area}

This study was developed in areas owned by a forestry company, located in the municipality of Campo Belo do Sul-SC, Brazil. The average altitude of the municipality is $950 \mathrm{~m}$, and the annual precipitation ranges from 1,300 to 2,400 $\mathrm{mm}$. The most prominent soil is the Hapudox, with Cambisol and Leptosol in areas of greater declivity (CAMPO BELO DO SUL, 2004).

The plantations evaluated, in general, underwent four to six thinning operations before clearcutting, depending on the development of the forest. Two different situations were assessed according to the company's demand to determine the variables that influence quality costs: one just after the fourth thinning (when the forest reaches 21 years of age) and the other after clearcutting (over 25 years of age) (Table 1).

Table 1. Characteristics of the evaluated situations: fourth thinning and clearcutting.

Tabela 1. Características das situações avaliadas: quarto desbaste e corte raso.

\begin{tabular}{lcc}
\hline \multicolumn{1}{c}{ Characteristics } & \multicolumn{2}{c}{ Interventions } \\
\cline { 2 - 3 } & $\mathbf{4}^{\text {th }}$ Thinning & Clear Cutting \\
\hline Species & Pinus elliottii & Pinus taeda \\
Age (years) & 21 & 34 \\
Total area (ha) & 32.8 & 174.5 \\
Planting distance $(\mathrm{m})$ & $2.0 \times 3.0$ & $2.0 \times 3.0$ \\
Diameter at breast height $(\mathrm{cm})$ & 31.3 & 45.8 \\
Mean height (m) & 24.6 & 34.8 \\
Mean individual volume $\left(\mathrm{m}^{3}\right)$ & 0.82 & 2.5 \\
Production expected at the intervention $\left(\mathrm{m}^{3} / \mathrm{ha}\right)$ & 120.0 & 582.3 \\
Declivity $\left({ }^{\circ}\right)$ & $0-5$ & $5-10 / 10-15$ \\
Trees removed at the intervention $(\mathrm{N} / \mathrm{ha})$ & 146 & 233 \\
\hline
\end{tabular}

The fourth thinning was carried out selectively, according to the development of the forest. In addition to thinning interventions, the planted area underwent silvicultural treatments, such as pruning, to obtain high-quality wood, without knots. Subsequently, clearcutting was carried out in the areas with over 25 years of age. The cut-

FLORESTA, Curitiba, PR, v. 50, n. 4, p. 1717 - 1724, out/dez 2020. 
to-length harvest system was used in mechanized modules and consists of a Harvester, Forwarder, and mechanical loader.

\section{Application of the QFD method}

This study sought to continue the work carried out in 2016 and later published by Garcia et al. (2020), who identified the critical success factors that occur in harvesting operations through three stages: process mapping, identifying and evaluating critical points, and process evaluation. Subsequently, the methodology described by Jacovine et al. (1999) was adopted, aiming to determine the variables that influence quality costs in the following categories: prevention, evaluation, and internal and external flaws.

The QFD method was adapted to determine the variables based on critical success factors. Initially, a team was organized with engineers, technicians responsible for the quality control of the harvest activities, employees, and those responsible for the research.

The elaboration of the quality house sought to evaluate the demands of the customers in order to reduce costs and improve the relationship with external customers (wood processing industry, represented in this research by the company's commercial department) and internal customers (forestry sector, responsible for preparing the area for a new cycle). This set configures the "desired quality", based on the critical success factors pointed out by Garcia et al. (2020) (assortments, stump height, trees left in the area) for the two interventions evaluated and damage to the remaining trees in the fourth thinning. Later, customer demands were split into variables that influence quality costs (technical characteristics). In a third stage, the relationship between the desired quality and the technical characteristics (relationship matrix) was determined. Then, weights were given for each relationship (projected quality), and, finally, the correlation between the technical characteristics was performed, forming the quality roof (correlation matrix).

\section{Desired quality (Critical success factors)}

The first phase of the matrix involves defining customer needs (internal and external). In this research, customer needs were treated as the critical success factors of the mechanized forest harvest process.

Thus, to define the items of the desired quality, the demands requested and considered fundamental by the companies that purchase the products were used. These items were submitted to analysis by the team responsible for the research to validate and verify the existence of other critical factors to be considered. Thus, the quality desired by customers in the proposed matrix was determined.

Afterward, the most relevant characteristics and services were identified, obtaining the degree of importance to meet the quality demanded by customers (internal and external), detecting which items are the most important for the mechanized forest harvesting process, assigning a weight from 1 to 5, according to the scale used by Likert et al. (1993).

In the phase of deploying the quality demanded in technical requirements, the attributes of variables that influence the quality costs that can be measured were defined, evaluating the fulfillment of customer demands (critical success factors). A literature review was carried out to obtain a more in-depth knowledge of which variables interfere in each category and, thus, adapt those that are most relevant and compatible with the company's reality. Subsequently, these attributes were allocated to the four categories of quality costs: prevention, evaluation, internal and external flaws.

The methodology presented by Govers (1996), which determines the intensity of each relationship in standardized symbols for the different weights $(9,3,1$, or 0 , if there is no correlation), was adapted to recognize the relationship between the critical success factors and the variables that influence the quality costs in the relationship matrix. Once again, the correlation was defined through the common sense of the team, individually integrating the correlations.

The matrix allowed the verification of the weights for each variable through the relationship between critical success factors and variables that influence quality costs, in order to highlight the most relevant variables for the mechanized forest harvesting process in the company, determined from the product between the degree of importance and the weight of the relationship between critical success factor and variable that influences the cost of quality, according to Equation 1 (MILAN et al., 2003).

$$
W_{i j}=G I_{i} \times P_{i j}
$$

where: $\mathrm{W}_{\mathrm{ij}}$ is the absolute weight of the relationship between the $\mathrm{i}^{\text {th }} \mathrm{CSF}$ (Critical Success Factors) and the $\mathrm{j}^{\text {th }}$ VQC (a variable that influences the quality cost); $\mathrm{GI}_{\mathrm{i}}$ is the degree of importance of the $\mathrm{i}$-th CSF; and $\mathrm{P}_{\mathrm{ij}}$ is the weight of the relationship between the $\mathrm{i}$-th CSF and the $\mathrm{j}^{\text {th }}$ VQC, according to the methodology described by Govers (1996).

FLORESTA, Curitiba, PR, v. 50, n. 4, p. 1717 - 1724, out/dez 2020 
The absolute weight of the variable that influences the cost was obtained by the sum of their respective absolute weights concerning the critical success factors ( $\mathrm{W}_{\mathrm{ij}}$ ), as shown in Equations 2 and 3 (MILAN et al., 2003).

$$
A W_{j}=\sum_{i=1}^{n} W_{i j}
$$

where: $\mathrm{AW}_{\mathrm{j}}$ is the absolute weight of the $\mathrm{j}^{\text {th }} \mathrm{VQC}$. Equation 3.

The relative weight, in percentage, of each variable that influences the quality cost was estimated by

$$
R W_{j}=\frac{A W_{j}}{\sum_{j=1}^{n} A W_{j}} \times 100
$$

where: $R W_{j}$ is the relative weight of the $\mathrm{j}^{\text {th }} \mathrm{VQC}$.

These weights indicated which variables influence the most important and critical costs for the success of the mechanized forest harvest activities developed by the company. The variables that influence quality costs were correlated in the last stage of structuring the matrix to help identify the existence of interdependence between them. Thus, the importance of correlating the variables that influence the costs of prevention and evaluation with flaw variables was verified. Therefore, the correlation classification was carried out using the methodology adapted from Govers (1996). The correlations were evaluated as strong, medium, weak, and non-existent.

\section{RESULTS}

The quality matrix represents the organization of the variables planning that influence the quality costs of the mechanized forest harvest using the QFD method. Thus, the team defined the variables that influence quality costs with their relative weight of the process in $\%$, by deploying the critical success factors, totaling 29 variables in the four categories (Table 3 ).

Table 3. Variables that influence the quality costs and their relative weights of the process in $\%$.

Tabela 3. Variáveis que influenciam os custos da qualidade e seus pesos relativos do processo em $\%$.

\begin{tabular}{llc}
\hline \multirow{2}{*}{ Cost categories } & \multicolumn{1}{c}{ Variables that influence the quality costs } & $\begin{array}{c}\text { Relative weight of the } \\
\text { process \% }\end{array}$ \\
& Quality planning; & 5.81 \\
& New product review; & 3.68 \\
& Process control; & 1.94 \\
& Data analysis and acquisition; & 5.81 \\
& Quality reports; & 1.94 \\
Prevention & Quality information; & 1.94 \\
& Project control; & 2.63 \\
& Quality measures and equipment control; & 2.74 \\
& Quality system maintenance; & 5.81 \\
& Quality administrative costs; & 1.94 \\
& Process study. & 1.94 \\
\hline Subtotal & & $\mathbf{3 7 . 1 7}$ \\
\hline \multirow{2}{*}{ Evaluation } & Raw material inspection; & 5.81 \\
& Equipment testing; & 3.89 \\
& Stock evaluation; & 3.68 \\
& Inspection and testing preparation costs; & 1.94 \\
& Purchase control costs; & 1.55 \\
& Quality statements and reports; & 5.81 \\
\hline Subtotal & Production testing. & 2.81 \\
\hline
\end{tabular}

FLORESTA, Curitiba, PR, v. 50, n. 4, p. 1717 - 1724, out/dez 2020

Oliveira, G. S. et.al.

ISSN eletrônico 1982-4688 


\begin{tabular}{llc}
\hline & Other internal costs; & 4.66 \\
& Shutdowns/holds. & 2.60 \\
\hline Subtotal & & $\mathbf{2 6 . 5 7}$ \\
\hline & Returned material; & 2.10 \\
\multirow{2}{*}{ External flaws } & Costs with warranty; & 2.98 \\
& Costs with concessions given to clients, discounts; & 2.98 \\
& Customer service. & 1.73 \\
\hline Subtotal & & $\mathbf{9 . 7 3}$ \\
\hline Total & & $\mathbf{1 0 0}$ \\
\hline
\end{tabular}

Therefore, the critical factors raised by Garcia et al. (2020) were: assortments, stump height, trees left in the area for the two interventions evaluated, and damage to the remaining trees in the fourth thinning. The "pretracing" for both interventions was added by the responsible team (Table 2).

Table 2. Degree of importance for critical success factors (CSF) for mechanized forest harvest activities.

Tabela 2. Graus de importância para os fatores críticos de sucesso (FCS) para as atividades de colheita florestal mecanizada.

\begin{tabular}{|c|c|c|}
\hline Activities & Critical Success Factors & Degree of Importance \\
\hline \multirow[t]{2}{*}{ Fourth thinning } & Assortments & 5.0 \\
\hline & Damages to the remaining trees & 4.5 \\
\hline thinning & Stump height & 3.0 \\
\hline \multirow{2}{*}{ clearcutting } & Trees left in the area & 3.5 \\
\hline & Pre-tracing & 2.5 \\
\hline
\end{tabular}

The correlation matrix was adjusted after identifying the projected quality. Thus, 334 correlations were found for a total of 406 cells: 195 (58\%) strong, 86 (26\%) medium, and 53 (16\%) weak.

\section{DISCUSSIONS}

Of the variables that influence quality costs, $37.17 \%$ were related to prevention, and $26.49 \%$ to evaluation. For the prevention costs category, three of the variables showed greater prominence in mechanized forest harvesting, with a relative weight of 5.81\%. "Quality planning", which includes the costs related to the definition of continuous strategies to accomplish the harvest activities, free of flaws. This variable adds the organization of necessary tactics to inform directives for employees throughout the business environment involved in the harvesting process.

"Data analysis and acquisition" was also highly relevant in this category, interfering in all the critical success factors by qualifying the flaws. Furthermore, it is fundamental in monitoring the effectiveness of the system, enabling procedure improvement. The "quality system maintenance" is the third variable to affect prevention costs, representing $5.81 \%$ of the total, and emphasizing the importance of continued use of tools and strategies in the production process. In this sense, the company must maintain its processes and its ability to meet customer requirements. This variable is highly relevant in the entire harvesting process due to the need to establish a maintenance schedule so that there are no interruptions in activities. The variables related to the most relevant evaluation cost were "raw material inspection", which provides greater security through a set of actions aimed at detecting non-conformities in the process; and "Quality demonstration and reports", which allow a detailed and agile analysis of productivity, both presenting a relative weight of $5.81 \%$.

Internal flaws represented $26.57 \%$ and external flaws, $9.73 \%$. The following factors are prominent in internal flaws: "use of rejected materials for other purposes", representing $4.66 \%$ of the relative weight since the company sells its logs in different assortments for multiple uses and, in some cases, a few logs are disqualified, indicating errors in planning; and "other internal costs", which were addressed for this work, considering a few sporadic costs that may occur somewhere in the process, such as wood stains that occur in warmer seasons. According to Slack et al. (2007), costs can be mitigated through efficiency, productivity, and better use of project capital. These measures are directly related to good administration and complete studies of the process.

The external flaws are associated with defects identified outside the company. The most relevant variables were "guarantees" and "concessions and discounts given to external customers", both representing $2.98 \%$ of the relative weight. This phase addresses flaws derived from the product and complaints, considering the loss of customer confidence, of time due to project deficiency, and in future sales. Thus, the external flaws variables are considered the most serious since they represent opportunities lost concerning new sales, the loss of new customers

FLORESTA, Curitiba, PR, v. 50, n. 4, p. 1717 - 1724, out/dez 2020.

Oliveira, G. S. et.al.

ISSN eletrônico 1982-4688 
due to poor quality and lost profits in potential customers. In this context, the variables that add to this category mean that the company was not able to detect the defects before shipping the products.

Therefore, it is essential to understand and analyze the variables that make up quality costs to mitigate flaws by measuring and recording them. These analyzes have a significant effect on the systematization of costs in a continuous manner, highlighting the most significant categories and their time distributions, to distribute the evaluation and prevention costs to reduce the costs of flaws, especially external ones that directly affect consumers.

The first critical success factor includes "damage to the remaining trees", which occur in thinning activities, mainly by machines used to log extraction between planting rows, possibly causing lesions to individuals that will be conducted to the following interventions. Thus, it is essential to use equipment sized in agreement with the spacing of the individuals during wood extraction and a training program for operators. The damage to remaining trees was the second critical factor with the highest degree of importance, showing quality losses to the final product. In this sense, it is essential to evaluate the remaining individuals, preventing them from being damaged in the following thinning (MACHADO, 2008).

The rigor and proportion of this critical factor cause damages to future rotations, resulting in reduced productivity of damaged individuals, especially in the first logs, which have greater added value. According to Lineros et al. (2003), the injuries caused by the machines can later be attacked by fungi, impairing the log quality and, therefore, causing significant economic expenditures. Malinovski (1998) found that 5\% of the remaining trees suffered some type of injury in the fourth thinning when analyzing the damage caused in Pinus taeda L. plantations using the cut-to-length harvesting system. Mcneel et al. (1992) reported that less than 5\% of the total of remaining trees suffered injuries during thinning when using the same system.

The critical success factor "assortments" presented the highest degree of importance among those evaluated, as it affects internal and external customers. Assortments are the sequence of multiple uses that can be obtained from a given stem, that is essential for the forest's yield. The non-conformities of this factor are characterized by flaws that occur when the logs have inappropriate dimensions and diametric classification, due to inaccuracies related to the activities of the Harvester or allocation of logs in the wood piles.

Among the factors that may have influenced the Harvester's inaccuracy are the terrain slope, soil class, volume per tree, operator experience, machine conditions, maintenance and operation direction. The flaws in the $\log$ separation in the piles are due to the calibration of the machines, operation planning, employee training, and the wide range of assortments sold by the company. The multiple uses of wood complicate decision making regarding the stem tracing. According to Oliveira and Lopes (2009), the use of different assortments for pine logs aims to serve the different consumers of a certain region. However, errors in the tracing can damage its use. Thus, the repair of this critical factor should allow the maximum financial yield, resulting in more profitable assortments (CAMPOS et al., 2013).

The "stump height", on the other hand, is classified as a critical factor due to the height exceeding $15 \mathrm{~cm}$ after forest harvest. The occurrence of stumps above the company specifications can occur in terrains with greater slopes and with rocky outcrops, resulting in a higher cut and causing damage to the machine, respectively. Such waste of wood occurs at the log of the most significant economic value and results in rework to lower stumps in future forests. Furthermore, this factor hinders future activities in the area, such as soil preparation and fertilization, by hampering the traffic of machines and implements. According to Foelkel (2014), one of the most significant challenges of forest harvesting is to carry out operations in such a way that the stumps are the closest to the ground as possible, maximizing the use of the thickest logs. In this sense, repairing this factor provides relevant improvements in terms of efficiency, safety, quality control, and operational performance.

"Pre-tracing" refers to the wooden disk eliminated from the log in order not to damage the first logs of the stem. This activity is performed when the forest presents large individuals as a safety measure for the Harvester. It is characterized as a critical factor when the wooden discs have heights exceeding $10 \mathrm{~cm}$ after mechanized forest harvesting. However, this factor had the lowest degree of importance due to lower losses when compared to the others.

The critical success factor "trees left in the area" comprises the cut raw material, with dimensions over $8.0 \mathrm{~cm}$ in diameter and $1.50 \mathrm{~m}$ in length. This factor occurs due to the lack of perception by employees during felling, processing, and extraction or by this material falling from the extraction machines. In most cases, the losses result from logs with dimensions of lower economic interests. However, they contribute to the final revenues expected.

In general, the cost categories showed a higher number of strong correlations, mainly in the evaluation and prevention variables. These categories ensure operation quality, such as adjustments, monitoring, inspection, tests, review, among others. Thus, the correlation between the variables allows us to detect improvements in specific projects and monitor them to optimize quality, thus, reducing the costs of poor quality, especially those of flaws. The identification of variables that influence the prevention and evaluation costs, which have a strong correlation with the costs of internal and external flaws, aim to create measures to mitigate customer dissatisfaction

FLORESTA, Curitiba, PR, v. 50, n. 4, p. 1717 - 1724, out/dez 2020.

Oliveira, G. S. et.al.

ISSN eletrônico 1982-4688 
and the respective threats to sales. According to Robles Jr. (1996), these categories ensure the quality of operations, such as adjustments, monitoring, inspection, tests, review, among others.

In this perspective, the "quality planning" variable in prevention category presented a stronger correlation with all flaw variables (internal and external), indicating that higher investments in planning would reduce flaws in the process and, consequently, its costs. Another prevention variable that showed a strong correlation with all flaw costs was "data analysis and acquisition", which allows the identification and organization of a specific noncompliance. Such results corroborate the need for research and analysis with a degree of certainty, increasing the perception of the teams involved in the harvesting process regarding problems, which may increase costs due to flaws.

The evaluation variable "quality demonstration and reports" showed a strong correlation with all external flaw variables, indicating that more significant resources spent on this type of evaluation will contribute to avoiding costs generated by the distribution of non-compliant or defective products. Thus, these results reveal the performance of these variables in reducing external flaws, generating reports with added information, and providing support in decision making. Moreover, quality reports must be practical, accessible, and easy to understand, presenting continuity, standardization and coherence, to enable periodic confrontation.

\section{CONCLUSIONS}

- The results obtained in this work showed that, despite the quality control in the company's forest harvest process presents a few variables that influence the costs of evaluation and prevention, and it still has many variables that influence the costs of flaws, especially internal.

- Among the 29 variables that influence quality costs, 18 were concentrated in the evaluation and prevention categories, showing that the company seeks to eliminate variables included in the costs of internal and external flaws.

- Critical success factors such as "damage to the remaining trees" and "assortments" showed high degree of importance, highlighting the need for greater attention on quality control since these affect external customers directly.

- The cost categories showed a higher number of strong correlations, mainly in evaluation and prevention variables, allowing the reduction of flaws in the process, as well as their costs, with higher investments.

\section{ACKNOWLEDGMENTS}

We thank the company Florestal Gateados LTDA and the Fundação de Amparo à Pesquisa e Inovação do Estado de Santa Catarina (FAPESC) for the financial support thougth the research group Gestão de Recursos Florestais.

\section{REFERENCES}

AKAO, Y.; MAZUR, G.H. The leading edge in QFD: past, present and future. Internacional Journal of Quality e Reliability Management, Reino Unido, v. 20, n.1, p. 20 - 35, 2003.

ASSOCIAÇÃO CATARINENSE DE EMPRESAS FLORESTAIS. Anuário estatístico de base florestal para o estado de Santa Catarina 2016 ano base 2015. 105 p. Lages/SC, 2016.

CAMPO BELO DO SUL. Usina Hidrelétrica Barra Grande. Campo Belo do Sul, jan. 2004. Disponível em: http://www.campobelodosul.sc.gov.br/cms/diretorio/index/codMapaItem/11969. Acesso em: 03 mar. 2017.

CAMPOS, B. P. F.; BINOTI, D. H. B.; SILVA, M. L.; LEITE, H. G.; BINOTI, M. S. Conversão de árvores em multiprodutos da madeira utilizando programação inteira. Revista Árvore, Viçosa, v. 37, n. 5, p. 881 - 887, 2013.

DIAS, A. F. J.; ANDRADE, C. R.; BRITO, J. O.; MILAN, M. Desdobramento da Função Qualidade (QFD) na Avaliação da Qualidade do Carvão Vegetal Utilizado para Cocção de Alimentos. Floresta e Ambiente, Seropédica, v. 22, n. 2, p. 262 - 270, 2015.

FOELKEL, C. O. Problema das cepas residuais das florestas plantadas de eucaliptos. Eucalyptus Newsletter, n. $45,2014$.

GARCIA, B. M.; SOARES, P. R. C.; SAMPIETRO, J. A.; FERNANDES, C. Predictability in the productive process of thinning and clearcutting mechanized operations in Pinus taeda L. Revista Floresta, Curitiba, v. 50, n. 1, p. $933-942,2020$.

FLORESTA, Curitiba, PR, v. 50, n. 4, p. 1717 - 1724, out/dez 2020. 
GOVERS, C. P. M. What and how about quality function deployment (QFD). International Journal of Production Economics, Amsterdam, v. 46 - 47, p. 575 - 585, 1996.

JACOVINE, L. A. G.; REZENDE, J. L. P.; SOUZA, A. P.; LEITE, H. G.; TRINDADE, C.; Descrição e uso de uma metodologia para avaliação dos custos da qualidade na Colheita Florestal Semimecanizada, Ciência Florestal, Santa Maria, v. 9, n. 1, p. 143 - 160, 1999.

JURAN, J. M.; GRYNA, F. M. Controle de qualidade: qualidade em diferentes sistemas de produção, v. 8, São Paulo: Makron Books, 1993.

LIKERT, R. ROSLOW, S.; MURPHY, G. A simple and reliable method of scoring the thurstone attitude scales. Personnel psychology, Athens, v. 46, p. 689 - 690, 1993.

MACHADO, C. C. Colheita Florestal. 3. ed. Viçosa: Editora UFV, 2014. 138 p.

MACHADO, C. C. Colheita Florestal. 2. ed. Viçosa: Editora UFV, 2008. 501 p.

MCNEEL, J.F.; BALLARD, T.M. Analysis of site stand impacts from thinning with a harvester-forwarder system. Journal of Forest Engineering, Vancouver, p. 23 - 29, 1992.

MILAN, M.; BARROS, J.W.D.; GAVA, J.L. Planning soil tillage using Quality Function Deployment (QFD). Scientia agrícola, Piracicaba, v. 60, n. 2, p. 217 - 221, 2003.

OLIVEIRA, D; LOPES, E; FIEDLER, N. Avaliação técnica e econômica do Forwarder na extração de toras de Pinus. Revista Scientia Forestalis, Piracicaba, v. 37, n. 84, p. 525 - 533, 2009.

SANTOS, C. K. M. S. dos; SILVA, H. G. B.; RODRIGUES, L. F.; SILVA, T. M.; CARNEIRO, M. B.; COSTA, F. H. O. de,; TABAH, J. Aplicação de ferramentas da gestão da qualidade no setor de corte de uma indústria de calçados. Revista das Engenharias. Revista das Engenharias (online), v.2, n.1, ed.1, p. 1 - 24, 2019.

SHANK, J. K., GOVINDARAJAN, V. A Revolução dos Custos “Como reinventar e redefinir sua estratégia de custos para vencer em mercados crescentemente competitivos”. Tradução de Luiz Orlando Coutinho Lemos. $8^{\text {a }}$ ed. Rio de Janeiro: Campus, 1997.

SLACK, N.; CHAMBERS, S.; HARRISON A.; JOHNSTON, R. Operations Management. $5^{\circ}$ ed. Trans-Atlantic Publications, Goring-by-Sea, 2007.

SOARES, P. R. C.; TIMOFEICZYK, R. J.; GARZEL, J. C.; SILVA, L.; MILAN, M.; Sistema de medição de performance para o controle de plantas invasoras em plantações florestais. Revista Floresta, Curitiba, v. 45, n. 1, p. $175-184,2015$.

FLORESTA, Curitiba, PR, v. 50, n. 4, p. 1717 - 1724, out/dez 2020. 